\title{
REKAYASA PRODUKSI INDIKATOR OKSIGEN SEBAGAI PENDETEKSI KEBOCORAN KEMASAN
}

\section{PRODUCTION DESIGN OF OXYGEN INDICATOR AS PACKAGING LEAKAGE DETECTOR}

\author{
Fitri Muslimah, Endang Warsiki, dan Ika Amalia Kartika \\ Departemen Teknologi Industri Pertanian, FakultasTeknologi Pertanian, Institut Pertanian Bogor \\ Kampus IPB Darmaga, Bogor 16680, Jawa Barat, Indonesia \\ Email: endangwarsiki@apps.ipb.ac.id
}

Makalah: Diterima 10 Agustus 2018; Diperbaiki 8 Novembr 2018; Disetujui 27 November 2018

\begin{abstract}
Handling improper packaging can lead to decrease the quality of product. This can be caused by a leakage in the packaging so that the gas and water enter the packaging. Efforts are made to inform early of the leaking by attaching the package with indicator which called leakage indicator. The aims of this research were to formulate, characterize and examine the performance of leakage indicator. The factors investigated were the effect of the amount of $\mathrm{Ca}(\mathrm{OH})_{2}$ added $(1-8 \mathrm{~g})$ in the formula, the mole ratio of glucose to methylene blue (0.8:14.8:1) and the concentration of methylene blue (1-2\%)on duration of glucose to reduct methylene blue, sensitivity time, water content, irreversible property and performance of leakage indicator.The results showed thatthe best formula of indicator were 7 and $8 \mathrm{~g}$ of $\mathrm{Ca}(\mathrm{OH})_{2}, 0.8: 1-2.8: 1$ of mole ratio of glucose to methylene blue and $2 \%$ of concentration of methylene blue. The analysis ofvariance showedthat the amount of $\mathrm{Ca}(\mathrm{OH})_{2}$ and the mole ratio of glucose to methylene blue affected the time of reduction and water content while the sensitivity time was only influenced by the mole ratio of glucose to methylene blue.The best leakage indicator was obtained from the amount of $\mathrm{Ca}(\mathrm{OH})_{2}$ of $8 \mathrm{~g}$ and the mole ratio of glucose to methylene blue of 1.8:1. The leakage indicator had irreversible property with reduction time of $72 \mathrm{~min}$, sensitivity time of $31 \mathrm{~s}$ and water content of $10.85 \%$. The response of oxygen indicator showedthat the colour changedfrom white to purple.
\end{abstract}

Keywords: leakage detector,methylene blue, oxygen indicator

\section{ABSTRAK}

Penanganan kemasan yang kurang baik mengakibatkan mutu produk menjadi menurun bahkan rusak. Hal ini dapat disebabkan karena adanya kebocoran pada kemasan yang mengakibatkan gas dan airmasuk ke dalam kemasan. Upaya yang dilakukan dalam mengatasi hal tersebut adalah dengan melampirkan indikator pada kemasan yang disebut indikator kebocoran kemasan.Tujuan dari penelitian ini adalah untuk memformulasi, mengkarakterisasi dan menguji kinerja indikator kebocoran. Faktor-faktor yang diinvestigasi adalah pengaruh jumlah $\mathrm{Ca}(\mathrm{OH})_{2}$ yang ditambahkan $(1-8 \mathrm{~g})$ ke dalam formula, rasio mol glukosa terhadap metilen biru $(0,8: 1$ 4,8:1) dan konsentrasi metilen biru (1-2\%)terhadap lama waktu glukosa mereduksi metilen biru, waktu sensitivitas, kadar air dan sifat irreversible serta kinerja indikator sebagai pendeteksi kebocoran kemasan. Hasil pengamatan menunjukkan formula bubuk indikator terbaik adalahjumlah $\mathrm{Ca}(\mathrm{OH})_{2}$ yang ditambahkan sebesar 7 dan $8 \mathrm{~g}$, rasio mol glukosa terhadap metilen biru 0,8:1-2,8:1,serta konsentrasi metilen biru sebesar 2\%. Analisis keragaman menunjukkan bahwa jumlah $\mathrm{Ca}(\mathrm{OH})_{2}$ yang ditambahkan dan rasio mol glukosa terhadap metilen biru mempengaruhi waktu reduksi dan kadar air sedangkan sensitivitas hanya dipengaruhi oleh rasio mol glukosa terhadap metilen biru. Indikator kebocoran terbaik diperoleh dari perlakuan jumlah $\mathrm{Ca}(\mathrm{OH})_{2}$ sebesar $8 \mathrm{~g}$ dan rasio mol glukosa terhadap metilen biru 1,8:1. Indikator kebocoran tersebut memiliki sifat irreversible dengan waktu reduksi 72 menit, waktu sensitivitas 31 detik dan kadar air sebesar 10,85\%. Respon indikator oksigen secara visual memperlihatkan perubahan warna dari putih menjadi ungu ketika kontak dengan oksigen.

Kata kunci: pendeteksi kebocoran, indikator oksigen, metilen biru

\section{PENDAHULUAN}

Kemasan memiliki fungsi utama dalam melindungi, mewadahi, memudahkan selama transportasi dan mempromosikan produk yang dikemas. Kemasan memiliki fungsi penting dalam melindungi mutu produk di dalam kemasan. Penanganan kemasan yang kurang baik dapat mengakibatkan mutu produk menjadi menurun bahkan rusak. Salah satu permasalahan pada kemasan adalah kebocoran yang menyebabkan gas seperti oksigen dari lingkungan sekitarnya masuk ke dalam kemasan. Oksigen merupakan salah satu faktor utama yang sering menyebabkan terjadinya kerusakan bahan pangan, seperti kebusukan makanan, pencoklatan pada buah dan sayuran, perombakan asam askorbat dan perubahan rasa makanan akibat reaksi oksidasi (Mills, 2005)

Perkembangan teknologi kemasan melahirkan suatu kemasan yang memiliki fungsi 
lebih selain dari fungsi utama. Kemasan ini dikenal dengan sebutan kemasan cerdas, yaitu sistem kemasan yang mampu melaksanakan fungsi cerdas (seperti mendeteksi, sensor, merekam, melacak, berkomunikasi dan menerapkan logika ilmiah) untuk memperpanjang umur simpan, meningkatkan keamanan produk, menjaga kualitas dan memberikan informasi mengenai kondisi produk yang dikemas (Yam et al., 2005).

Salah satu kemasan cerdas adalah kemasan berindikator. Kemasan ini dapat mengidentifikasi keberadaan suatu jenis gas berlebih akibat kebocoran pada kemasan melalui perubahan warna pada indikator. Indikator kebocoran (leakage indicator) juga dapat memberikan informasi tentang integritas kemasan selama proses distribusi. Studi indikator kebocoran belum banyak dilakukan. Oleh karena itu masih diperlukan studi lebih lanjut tentang pembuatan indikator kebocoran, mekanisme kerja, stimulasi pemakaian dan lain-lain.

Indikator kebocoran yang dikembangkan pada penelitian ini adalah indikator warna. Glukosa digunakan sebagai agen pereduksi,metilen biru sebagai agen pewarna dan $\mathrm{Ca}(\mathrm{OH}) 2$ untuk mempercepat reaksi pada indikator. Metilen biru dapat berubah warna secara reversible akibat reaksi oksidasi dan reduksi (Sumitani et al., 2004). Metilen biru berubah menjadi tidak berwarna ketika tidak adanya oksigendan berubah menjadi biru ketika kontak dengan oksigen (Kaas et al., 2010). Studi ini bertujuan untuk memformulasi, mendesain dan menguji kinerja indikator kebocoran. Faktor-faktor yang diinvestigasi adalah pengaruh jumlah $\mathrm{Ca}(\mathrm{OH})_{2}$ yang ditambahkan, rasio mol glukosa terhadap metilen birudan konsentrasi metilen biru pada lama waktu glukosa mereduksi metilen biru, waktu sensitivitas, kadar air dan sifat irreversible serta kinerja indikator.

\section{METODE PENELITIAN}

\section{Bahan dan Alat}

Bahan yang digunakan dalam penelitian ini meliputi LDPE (low density polyethylene), metilen biru, glukosa kristal (dextrose monohydrate) dan $\mathrm{Ca}(\mathrm{OH})_{2}$. Alat yang digunakan dalam penelitian ini meliputi erlenmeyer $125 \mathrm{~mL}$, pengaduk, stopwatch, pencetak tablet manual, colorimeter model NR60CP/NR110/NR10QC/NR145/NR20XE dan peralatan lainnya.

\section{Tahapan Penelitian}

Formulasi IndikatorKebocoran

Penentuan Jumlah $\mathrm{Ca}(\mathrm{OH})_{2}$

Tahapan pertama dari penelitian ini adalah menentukan jumlah $\mathrm{Ca}(\mathrm{OH})_{2}$ yang diperlukan dalam memenuhi syarat ideal sebagai indikator oksigen. Kehalusan bubuk akan mempengaruhi proses pembuatan indikator dalam bentuk tablet. Jumlah $\mathrm{Ca}(\mathrm{OH})_{2}$ yang ditambahkan yaitu 1-8 g. Indikator dibuat dengan mencampurkan 1-8 $\mathrm{gCa}(\mathrm{OH})_{2}, 1 \mathrm{~g}$ glukosa kristal dan $1 \mathrm{~mL}$ metilen biru $1 \%$. Pengamatan tekstur dilakukan secara fisik pada produk formulasi yang dihasilkan. Jumlah $\mathrm{Ca}(\mathrm{OH})_{2}$ yang memberikan tekstur kehalusan terbaik akan dijadikan dasar untuk studi selanjutnya.

\section{Penentuan Rasio Mol Glukosa Terhadap Metilen} $\underline{B i r u}$

Tahapan selanjutnya adalah penentuan jumlah mol glukosa yang diperlukan dalam mereduksi metilen biru. Hal ini ditandai dengan perubahan warna bubuk indikator dari ungu menjadi putih, kemudian menjadi ungu kembali ketika kontak dengan oksigen. Variasi rasio mol glukosa terhadap metilen biru yang digunakan adalah $0,8: 1$, 1,8:1, 2,8:1, 3,8:1 dan 4,8:1. Perubahan warna bubuk indikator dilakukan secara visual menggunakan kamera. Penentuan rasio mol glukosa terhadap metilen biru terbaik didasarkan pada formula dengan perubahan warna yang jelas secara visual. Hasil terbaik dari studi ini dijadikan dasar pada studi selanjutnya.

\section{Penentuan Konsentrasi Metilen Biru}

Konsentrasi metilen biru perlu ditentukan agar pengamtan terhadap perubahan warna yang terjadi dapat dilakukan dengan mudah. Konsentrasi metilen biru yang digunakan $1 \%$ dan $2 \%$. Indikator dibuat dengan mencampurkan $\mathrm{Ca}(\mathrm{OH})_{2}$ dan rasio mol glukosa terhadap metilen biru hasil dari studi sebelumnya. Pengamatan terhadap warna indikator ketika kontak dengan oksigen dilakukan secara visual menggunakan kamera.

\section{Karakterisasi Indikator Kebocoran}

Lama Waktu Glukosa Mereduksi Metilen Biru Pengamatan dilakukan secara visual melalui fotografi menggunakan kamera terhadap perubahan warna bubuk indikator setelah diaduk rata dan glukosa mereduksi metilen biru, yang ditandai dengan perubahan warna dari ungu menjadi putih.Pencatatan waktu dalam perubahan warna dilakukan menggunakan stopwatch.

\section{Waktu Sensitivitas}

Waktu sensitivitas ditentukan secara visualmelalui fotografi menggunakan kamera. Waktu sensitivitas adalah waktu yang diperlukan untuk merubah warna indikator dari putih hingga menjadi ungu. Pencatatan waktu dalam perubahan warna dilakukan menggunakan stopwatch.

\section{$\underline{\text { Kadar Air (AOAC 1995) }}$}

Kadar air yang dimaksud adalah kadar air bubuk indiaktor. Kadar air yang diharapkan berkisar antara $7-10 \%$. Jika kadar air $>10 \%$ tablet akan sulit terbentuk, bentukan tidak rata dan lengket. Jika kadar air $<7 \%$ tablet mudah hancur karena daya ikat antar partikel kurang kuat. 


\section{Irreversible}

Pengamatan dilakukan secara visual melalui fotografi menggunakan kamera. Pengujian dilakukan terhadap bubuk indikator yang sudah kontak dengan oksigen hingga berubah seluruhnya menjadi ungu yang kemudian dikemas kembali dan ditutup rapat. Selanjutnya diamati apakah warna ungu pada indikator kembali berubah ke warna semula (putih) atau tidak. Waktu irreversible ditentukan dengan menggunakan stopwatch.

\section{Rancangan Percobaan}

Rancangan percobaan yang digunakan adalah acak lengkap faktorial dengan 3 kali ulangan. Faktor yang dikaji berupa variasi jumlah $\mathrm{Ca}(\mathrm{OH})_{2}$ yang ditambahkan dan rasio mol glukosa terhadap metilen biru. Analisis data menggunakan ANOVA serta uji lanjut DMRT (Duncan's Multiple Range Test) dengan $\alpha=0,05$. Model matematis rancangan percobaan secara umum adalah sebagai berikut (Mattjik dan Sumertaya 2000) :

$Y i j k=\mu+\alpha i+\beta j+(\alpha \beta) i j+\varepsilon i j k$

Keterangan:

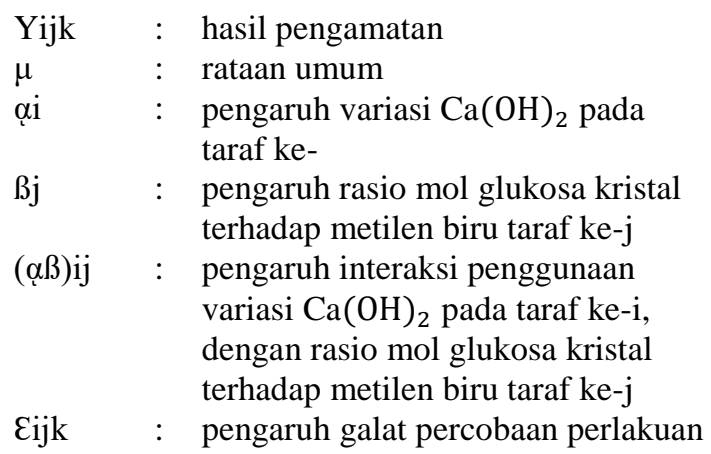

\section{Uji KinerjaIndikator Kebocoran}

Formulasi indikator terbaik dicetak dalam bentuk tablet dengan ukuran diameter $1 \mathrm{~cm}$, lebar $0,5 \mathrm{~cm}$ dan berat $0,77 \mathrm{~g}$. Indikator dikemas menggunakan plastik LDPE vakum. Indikator tablet yang sudah dikemas dan siap untuk digunakan dimasukkan ke dalam desikator dan dikondisikan minim udara dengan cara vakum. Selanjutnya, desikator dialiri udara bertekanan $1 \mathrm{~atm}$ dengan laju alir $2 \mathrm{~L} /$ menit pada selang waktu 30, 60, 90 dan 120 menit (Gambar 1). Perubahan warna diamati setiap 2 jam sampai warna ungu konstan.Respon perubahan warna yang diamati yaitu ketika indikator berubah warna dari putih menjadi ungu konstan. Pengamatan dilakukan secara visual dan dikuantifikasi menggunakan colorimeter model NR60CP/NR110/ NR10QC/NR145/NR20XE. Waktu pengamatan diukur menggunakan stopwatch. Data diplot menggunakan sistem notasi Munsell dengan atribut nilai warna, yang terdiri dari warna kromatik $\left({ }^{\circ} h u e\right)$ (Andarwulan et al., 2011) dan dihitung laju perubahan warna berdasarkan reaksi orde 0 pada persamaan (2) atau orde 1 pada persamaan (3) (Mashitoh et al., 2013). Gambar 1 menunjukkan skema pengukuran kinerja tablet indikator kebocoran.

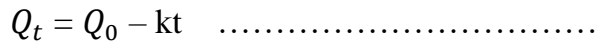

$$
\begin{aligned}
& Q_{t}=Q_{0} e^{-\mathrm{kt}}
\end{aligned}
$$

Keterangan:

$$
\begin{array}{ccl}
Q_{t} & : \text { perubahan warna pada waktu t menit } \\
Q_{0} & : \text { perubahan warna pada waktu } 0 \text { menit } \\
\mathrm{k} & : \text { konstanta } \\
\mathrm{t} & : \text { waktu (menit) }
\end{array}
$$

\section{HASIL DAN PEMBAHASAN}

Hasil pengamatan fisik bubuk indikator berdasarkan jumlah $\mathrm{Ca}(\mathrm{OH})_{2}$ yang ditambahkan ke dalam formula disajikan pada Tabel 1. Bubuk indikator dengan jumlah $\mathrm{Ca}(\mathrm{OH})_{2} \quad 7$ dan $8 \mathrm{~g}$ menghasilkan tekstur bubuk yang halus secara fisik, tidak ada gumpalan dan berwarna putih keabuan. Hal ini memenuhi syarat ideal dari indikator, yaitu memiliki tekstur yang halus (Mills, 2005). Jumlah $\mathrm{Ca}(\mathrm{OH})_{2}$ yang ditambahkan 1-3 g menghasilkan bubuk dengan tekstur menggumpal dan berwarna coklat. Hal ini dimungkinkan karena tingginya kandungan air, sedangkan warna coklat timbul akibat adanya reaksi antara glukosa dan $\mathrm{Ca}(\mathrm{OH})_{2}$.

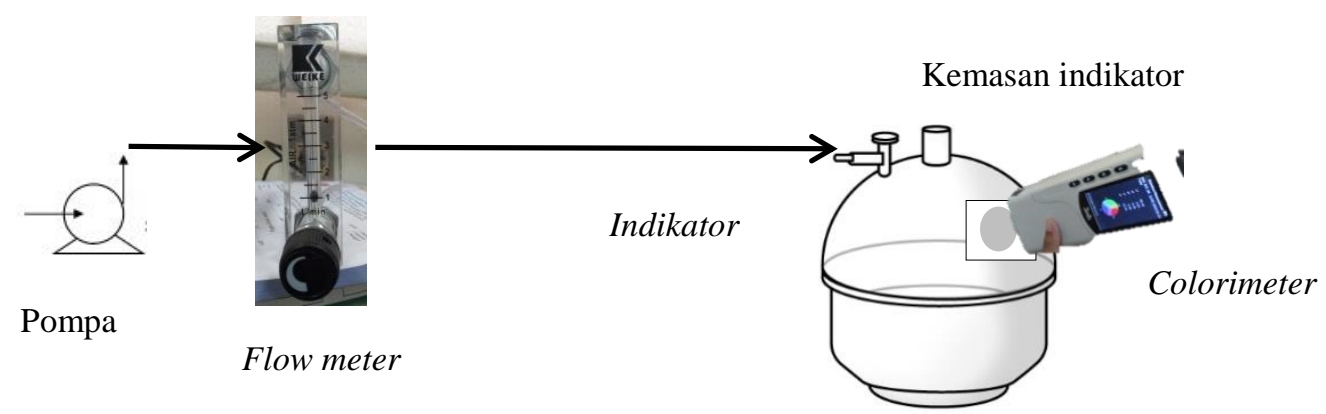

Ilustrasi

Desikator 
Gambar 1. Skema pengukuran kinerja tablet indikator kebocoran

Tabel 1. Tekstur indikator kebocoran yang dihasilkan pada berbagai jumlahCa $(\mathrm{OH})_{2}$ yang ditambahkan

\begin{tabular}{|c|c|c|c|c|c|c|c|c|}
\hline Jumlah & $1 \mathrm{~g}$ & $2 \mathrm{~g}$ & $3 \mathrm{~g}$ & $4 g$ & $5 \mathrm{~g}$ & $6 \mathrm{~g}$ & $7 \mathrm{~g}$ & $8 \mathrm{~g}$ \\
\hline \multirow{3}{*}{$\begin{array}{l}\text { Tekstur } \\
\text { produk }\end{array}$} & & & & & & & & \\
\hline & & & & & & & & \\
\hline & I & I & I & II & II & III & IV & IV \\
\hline
\end{tabular}

Keterangan : I = menggumpal, II = bubuk kasar, III = bubuk agak halus, IV = bubuk halus

$$
\text { Pada penambahan jumlah }
$$

$\mathrm{Ca}(\mathrm{OH})_{2}$ sebanyak 4-6 g, kandungan air bubuk masih cukup tinggi sehingga menghasilkan tekstur kasar (menggumpal) hingga agak halus dan berwarna abu-abu. Semakin besar jumlah $\mathrm{Ca}(\mathrm{OH})_{2}$ yang ditambahkan maka tekstur bubuk yang dihasilkan akan menyerupai sifat fisik dari $\mathrm{Ca}(\mathrm{OH})_{2}$ itu sendiri yaitu berupa bubuk halus. Kalsium hidroksida yang berupa bubuk putih menurut Siqueira dan Lopes (1999), memiliki sifat kurang larut dalam air (sekitar $1,2 \mathrm{~g} / \mathrm{L}$ pada suhu $25^{\circ} \mathrm{C}$ ).

Hasil studi penentuan rasio mol glukosa terhadap metilen biru disajikan pada Tabel 2 . Peningkatan rasio mol glukosa terhadap metilen biru dari 0,8:1 menjadi 2,8:1 memberikan perubahan warna yang jelas dari biru atau ungu menjadi putih hingga menjadi biru atau ungu kembali ketika kontak dengan oksigen. Warna ungu yang dihasilkan juga lebih pekat dibandingkan dengan rasio mol lainnya (3,8:1 dan 4,8:1). Menurut Mills (2005), glukosa teroksidasi ketika kontak dengan oksigen dan membentuk air sehingga peningkatan jumlah glukosa yang ditambahkan akan memudarkan warna bubuk. Glukosa sebagai gula pereduksi memiliki struktur kimia berbentuk rantai terbuka sehingga mudah mengalami proses enolisasi, dimana glukosa akan mereduksi metilen biru menjadi tidak berwarna (Whistler dan Daniel, 1985). Menurut Mills (2005), glukosa mereduksi metilen biru menjadi leukometilen biru, yang ditandai dengan perubahan warna menjadi putih, dan ketika kontak dengan oksigen leukometilen biru teroksidasi menjadi metilen biru kembali dengan perubahan warna yang kembali menjadi biru atau ungu, seperti yang dijelaskan pada Gambar 2.<smiles></smiles>

Metilen biru (MB), biru Reduktan<smiles>CN(C)c1ccc2c(c1)Sc1cc(N(C)C)ccc1N2</smiles>

Leukometilen biru (LMB), tidak berwarna
Gambar 2. Mekanisme perubahan warna metilen biru (Sumitani et al., 2004)

Hasil studi penentuan konsentrasi metilen biru disajikan pada Tabel 3, yang menunjukkan peningkatan konsentrasi metilen biru dari $1 \%$ menjadi $2 \%$ telah meningkatkan warna ungu menjadi lebih pekat dan dapat teramati oleh mata. Semakin tinggi konsentrasi metilen biru yang ditambahkan maka secara visual warna bubuk indikator semakin pekat. Konsentrasi berbanding lurus dengan kepekatan warna. Luas permukaan indikator bubuk indikator menyebabkan indikator lebih cepat teroksidasi ketika kontak dengan oksigen. Menurut Smolander et al.(1997), metilen biru adalah pewarna yang paling umum digunakan dalam indikator oksigen, berwarna putih dalam keadaan direduksi dan warna biru dalam keadaan teroksidasi.

Berdasarkan hasil ketiga studi tersebut, formula yang menghasilkan bubuk indikator kebocoran terbaik disajikan pada Tabel 4. Hal ini didasarkan pada formulasi yang menghasilkan tekstur bubuk indikator yang halus serta berwarna ungu pekat yang teramati langsung oleh mata ketika kontak dengan oksigen

\section{Karakteristik Indikator Kebocoran Oksigen \\ Lama Waktu Glukosa Mereduksi Metilen Biru}

Semakin cepat waktu yang dibutuhkan maka semakin sensitif pula bubuk indikator dalam mendeteksi adanya kebocoran pada kemasan. Hasil pengamatan lama waktu glukosa mereduksi metilen biru ditunjukkan pada Gambar 3.

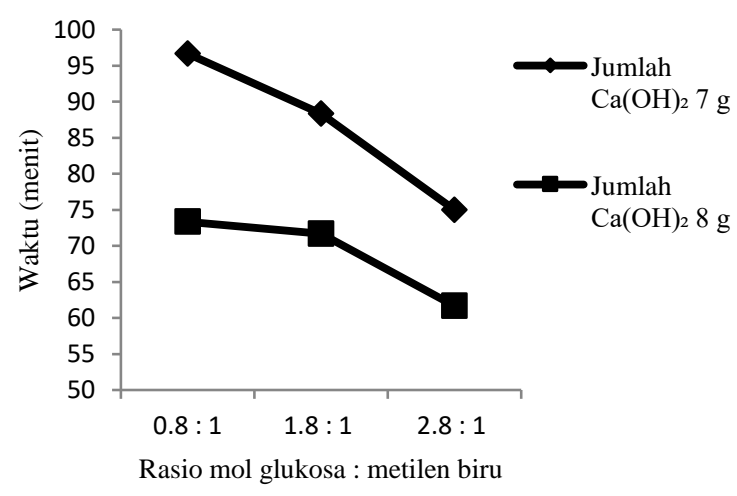

Gambar 3. Pengaruh jumlah $\mathrm{Ca}(\mathrm{OH})_{2}$ yang ditambahkan dan rasio mol glukosa : 
metilen biru terhadap lama waktu

glukosa mereduksi metilen biru

Tabel 2. Perubahan warna indikator kebocoran pada rasio mol glukosa terhadap metilen biru

\begin{tabular}{llll}
\hline $\begin{array}{l}\text { Rasio mol glukosa } \\
\text { terhadap metilen biru }\end{array}$ & $\begin{array}{l}\text { Setelah dicampur } \\
\text { dan diaduk }\end{array}$ & $\begin{array}{l}\text { Setelah didiamkan } \\
\text { beberapa waktu }\end{array}$ & $\begin{array}{l}\text { Setelah kontak } \\
\text { dengan udara }\end{array}$ \\
\hline $0,8: 1$ & & \\
$1,8: 1$ & \\
\hline $3,8: 1$ & \\
\hline
\end{tabular}

Tabel 3. Perubahan warna indikator kebocoran pada berbagai konsentrasi metilen biru

\begin{tabular}{cccc}
\hline $\begin{array}{c}\text { Konsentrasi } \\
\text { metilen biru }\end{array}$ & $\begin{array}{c}\text { Setelah dicampur dan } \\
\text { diaduk }\end{array}$ & $\begin{array}{c}\text { Setelah didiamkan } \\
\text { beberapa waktu }\end{array}$ & $\begin{array}{c}\text { Setelah kontak } \\
\text { dengan udara }\end{array}$ \\
\hline $1 \%$ & & & \\
\hline
\end{tabular}

Tabel 4.Formula terbaik untuk pembuatan indikator kebocoran oksigen

\begin{tabular}{cc} 
Faktor A & Faktor B \\
Jumlah $\mathbf{C a}(\mathbf{O H})_{\mathbf{2}}$ yang ditambahkan $(\mathrm{g})$ & Rasio molglukosa:metilen biru 2\% \\
\hline 7 & $0,8: 1$ \\
8 & $1,8: 1$ \\
& $2,8: 1$ \\
\hline
\end{tabular}

Hasil analisis keragaman menunjukkan bahwa jumlah $\mathrm{Ca}(\mathrm{OH})_{2}$ yang ditambahkan dan rasio mol glukosa terhadap metilen biru berpengaruh nyata pada lama waktu glukosa mereduksi metilen biru. Hasil uji lanjut Duncan menunjukkan penggunaan $\mathrm{Ca}(\mathrm{OH})_{2}$ sebanyak $8 \mathrm{~g}$ merupakan perlakuan terbaik. Rasio mol glukosa terhadap metilen biru pada 2,8:1 menghasilkan waktu paling cepat yaitu 62 menit dibandingkan dengan rasio mol 0,8:1 dan 1,8:1.

Hasil tersebut lebih baik jika dibanding indikator oksigen yang diproduksi oleh Mitsubishi Gas Chemical Company yaitu Ageless-Eye ${ }^{\mathrm{TM}}$, yang membutuhkan waktu 2-3 jam (Milss 2005). 
Peningkatan jumlah $\mathrm{Ca}(\mathrm{OH})_{2}$ yang ditambahkan dapat mempersingkat waktu reduksi. $\mathrm{Ca}(\mathrm{OH})_{2}$ menyebabkan kondisi bubuk menjadi basa sehingga mempercepat glukosa mereduksi metilen biru. Menurut Whistler dan Daniel (1985), asam atau basa dapat berfungsi sebagai katalis untuk proses tersebut, namun penggunaan basa lebih efektif dibandingkan asam. Begitu juga dengan peningkatan rasio mol glukosa sebagai agen pereduksi, semakin besar rasio mol glukosa yang ditambahkan maka jumlah agen pereduksi semakin besar sehingga proses reduksi berjalan lebih cepat.

\section{Waktu Sensitivitas}

Hasil pengamatan waktu sensitivitas disajikan pada Gambar 4. Hasil analisis keragaman menunjukkan bahwa rasio mol glukosa terhadap metilen biru berpengaruh nyata pada sensitivitas indikator kebocoran. Hasil uji lanjut Duncan menunjukkan bahwa rasio mol glukosa terhadap metilen biru 1,8:1 dan 2,8:1 menghasilkan waktu tersingkat artinya memiliki sensitivitas terbaik yaitu kurang dari 35 detik. Hasil tersebut lebih singkat dibandingkan indikator oksigen yang diproduksi

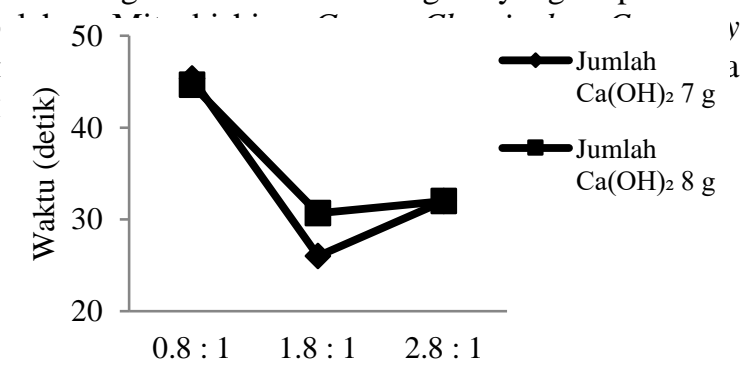

Rasio mol gluksa : metilen biru

Gambar 4. Pengaruh jumlah $\mathrm{Ca}(\mathbf{O H})_{2}$ yang ditambahkan dan rasio mol glukosa : metilen biru terhadap waktu sensitivitas

Indikator kebocoran oksigen ini menunjukkan warna putih ketika minim oksigen dan berwarna biru atau ungu ketika adanya oksigen. Hasil penelitian menunjukkan bahwa kinerja indikator tidak dipengaruhi oleh jumlah $\mathrm{Ca}(\mathrm{OH})_{2}$ yang ditambahkan. Sensitivitas indikator akan lebih sensitif ketika jumlah reduktan ditingkatkan, hal ini dikarenakan difusi yang cukup dari agen pereduksi terhadap metilen biru (Sumitani et al., 2004).

\section{Kadar air}

Tabel 5.Sifat irreversible bubuk indikator kebocoran fungsi dari waktu

\begin{tabular}{ccccccc}
\hline Jam ke-0 & Jam ke-4 & Jam ke-8 & Jam ke-12 & Jam ke-16 & Jam ke-20 & Jam ke-24 \\
\hline & & & & & \\
\end{tabular}

Kadar air bubuk indikator yang dihasilkan berkisar antara 10-15\%. Hasil analisis keragaman menunjukkan bahwa jumlah $\mathrm{Ca}(\mathrm{OH})_{2}$ yang ditambahkan dan rasio mol glukosa terhadap metilen biru berpengaruh nyata terhadap kadar air. Gambar 5 menunjukkan bahwa kadar air sekitar 10\% diperoleh pada jumlah $\mathrm{Ca}(\mathrm{OH})_{2} 8 \mathrm{~g}$ dan rasio mol glukosa terhadap metilen biru 1,8: 1 .

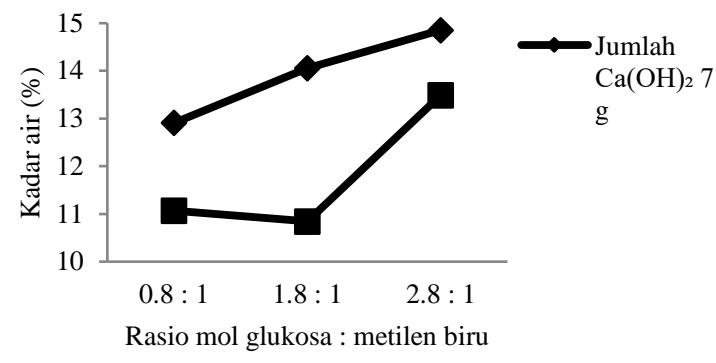

Gambar 5. Pengaruh jumlah $\mathrm{Ca}(\mathrm{OH})_{2}$ yang ditambahkan dan rasio mol glukosa : metilen biru terhadap kadar air

Peningkatan jumlah $\mathrm{Ca}(\mathrm{OH})_{2}$ yang ditambahkan menyebabkan kadar air dari bubuk indikator menjadi rendah. Jumlah padatan yang lebih banyak dibandingkan dengan larutan menyebabkan total padatan terlarut menjadi lebih banyak sehingga kadar air dari bubuk indikator menjadi rendah. Sebaliknya, peningkatan rasio mol glukosa terhadap metilen biru meningkatkan kadar air dari bubuk indikator. Menurut Winarno (1997), glukosa mempunyai kemampuan menarik air yang tinggi, sehingga peningkatan rasio mol glukosa terhadap metilen biru menyebabkan kadar air indikator menjadi tinggi. Kadar air dari indikator sangat berpengaruh terhadap kekompakan tablet indikator.

\section{Sifat Irreversible \\ Hasil pengamatan visual pada bubuk} indikator disajikan pada Tabel 5 menunjukkan bahwa semua formula bubuk indikator bersifat irreversible. Bubuk indikator yang sudah kontak dengan oksigen akan tetap berwarna ungu meskipun sudah dikemas kembali. Pengamatan dilakukan mulai jam ke-0 hingga pengamatan pada jam ke-24. Oksigen yang bersifat non polar dapat larut dalam air yang bersifat polar. Perbedaan sifat keelektronegatifan air dan oksigen menyebabkan tarik menarik sehingga oksigen larut dalam air namun perbedaan wujud fisik menyebabkan kelarutan oksigen dalam air menjadi kecil (Andarwulan, 2011). 
Berdasarkan hasil diatas, perlakuan terbaik diperoleh pada perlakuan jumlah $\mathrm{Ca}(\mathrm{OH})_{2}$ yang ditambahkan sebanyak $8 \mathrm{~g}$ dengan rasio mol glukosa terhadap metilen biru 2\% sebesar 1,8:1

\section{Kinerja Indikator Kebocoran}

Kinerja tablet indikator kebocoran dihitung dengan nilai ${ }^{\circ}$ hue, kemudian diplot pada grafik menggunakan model kinetika orde noldan satuyangmenghasilkan nilai persamaan serta koefisien korelasi $\left(\mathrm{R}^{2}\right)$. Dengan membandingkan nilai koefisien korelasi $\left(\mathrm{R}^{2}\right)$ orde nol dan orde satu maka dipilih $\mathrm{R}^{2}$ yang paling mendekati 1 .

Berdasarkan nilai koefisien korelasi $\left(\mathrm{R}^{2}\right)$, kinetika perubahan ${ }^{\circ}$ hue tablet indikator kebocoran dapat mengikuti reaksi orde nol dan orde satu. Menurut Mashitoh et al. (2013) reaksi oksidasi seperti pada tablet indikator kebocoran oksigen ini umumnya mengikuti orde nol. Agen pewarna metilen biru pada bahan indikator mengalami reaksi oksidasi ketika kontak dengan oksigen yang ditandai dengan perubahan warna dari putih keabuan menjadi biru atau ungu.

Tabel 6 menunjukkan bahwa nilai $\mathrm{k}$ pada tablet indikator meningkat dengan peningkatan lama waktu alir udara. Hal ini disebabkan karena banyaknya gas yang kontak dengan tablet indikator,sehingga tablet indikator menjadi lebih cepat teroksidasi. Dengan semakin lamanya waktu alir udara yang diberikan maka waktu tablet indikator mencapai warna konstan juga semakin singkat (Gambar 7).

Reaksi orde nol dicirikan dengan nilai laju perubahan warna yang konstan. Artinya, warna tablet indikator kebocoran berubah dengan laju yang sama pada satu satuan waktu yang sama. Selanjutnya laju perubahan warna tablet indikator ini juga dapat mengikuti orde satu. Reaksi orde satu dicirikan dengan peningkatan laju reaksi secara eksponential. Artinya, laju perubahan warna semakin cepat pada satu satuan waktu yang sama. Namun demikian laju perubahan warna $(\mathrm{k})$ reaksi orde nol lebih besar dibandingkan dengan laju perubahan warna (k) reaksi orde 1. Hal ini disebabkan karena pada satu waktu (t) yang sama nilai Qt orde nol dan orde 1 adalah sama. Namun demikian nilai $\mathrm{k}$ yang tinggi menunjukkan bahwa reaksi orde nol lebih reaktif dibandingan reaksi orde satu. Fenomena yang teramati pada penelitian ini juga teramati oleh penelitian sebelumnya seperti Fitria et al. (2012) tentang perubahan label indikator klorofil daun singkong, Mohammadi et al. (2008) tentang model kinetika perubahan warna pada irisan kiwi selama pengeringan udara, dan lain-lain. Oleh karena dapat disimpulkan bahwa perubahan warna tablet indikator dapat digambarkan sebagai reaksi orde nol.

Nilai ${ }^{\circ}$ hue menyatakan warna sebenarnya. Secara umum, nilai ${ }^{\circ}$ hue berkisar antara $24^{\circ}-61^{\circ}$ (merah) hingga $340^{\circ}-359^{\circ}$ (ungu). Hasil pemetaan nilai ${ }^{\circ}$ hue pada sistem warna Munsell dapat dilihat pada Gambar 8 .

Tabel 6. Model kinetika reaksi dari perubahan warna tablet indikator kebocoran

\begin{tabular}{ccccccc}
\hline \multirow{2}{*}{$\begin{array}{c}\text { Lama waktu alir } \\
\text { udara (menit)* }\end{array}$} & \multicolumn{2}{c}{ Orde 0 } & \multicolumn{3}{c}{ Orde 1 } \\
\cline { 2 - 7 } $\boldsymbol{Q}_{\boldsymbol{t}}=\boldsymbol{Q}_{\mathbf{0}}-\mathbf{k t}$ & $\mathbf{k}$ & $\mathbf{R}^{\mathbf{2}}$ & $\boldsymbol{Q}_{\boldsymbol{t}}=\boldsymbol{Q}_{\mathbf{0}} \boldsymbol{e}^{-\mathbf{k t}}$ & $\mathbf{k}$ & $\mathbf{R}^{\mathbf{2}}$ \\
\hline 30 & $\mathrm{Q}_{\mathrm{t}}=60,87-0,88 \mathrm{t}$ & 0,88 & 0,88 & $\mathrm{Q}_{\mathrm{t}}=60,87 e^{-0,02 \mathrm{t}}$ & 0,02 & 0,86 \\
60 & $\mathrm{Q}_{\mathrm{t}}=56,31-2,13 \mathrm{t}$ & 2,13 & 0,96 & $\mathrm{Q}_{\mathrm{t}}=56,31 e^{0,05 \mathrm{t}}$ & 0,05 & 0,96 \\
90 & $\mathrm{Q}_{\mathrm{t}}=46,74-2,68 \mathrm{t}$ & 2,68 & 0,75 & $\mathrm{Q}_{\mathrm{t}}=46,74 e^{0,07 \mathrm{t}}$ & 0,07 & 0,82 \\
120 & $\mathrm{Q}_{\mathrm{t}}=24,29-4,32 \mathrm{t}$ & 4,32 & 0,79 & $\mathrm{Q}_{\mathrm{t}}=24,29 e^{0,27 \mathrm{t}}$ & 0,27 & 0,83 \\
\hline
\end{tabular}

*Laju alir $2 \mathrm{~L} / \mathrm{menit}$

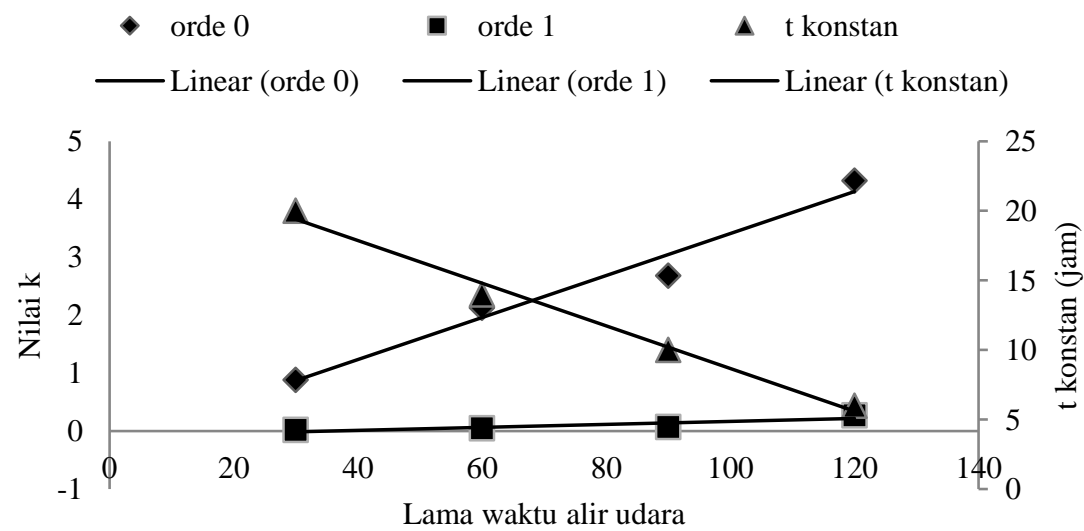

Gambar 7. Hubungan antara lama waktu alir udara dengan nilai $\mathrm{k}$ dan $\mathrm{t}_{\mathrm{konstan}}$ 


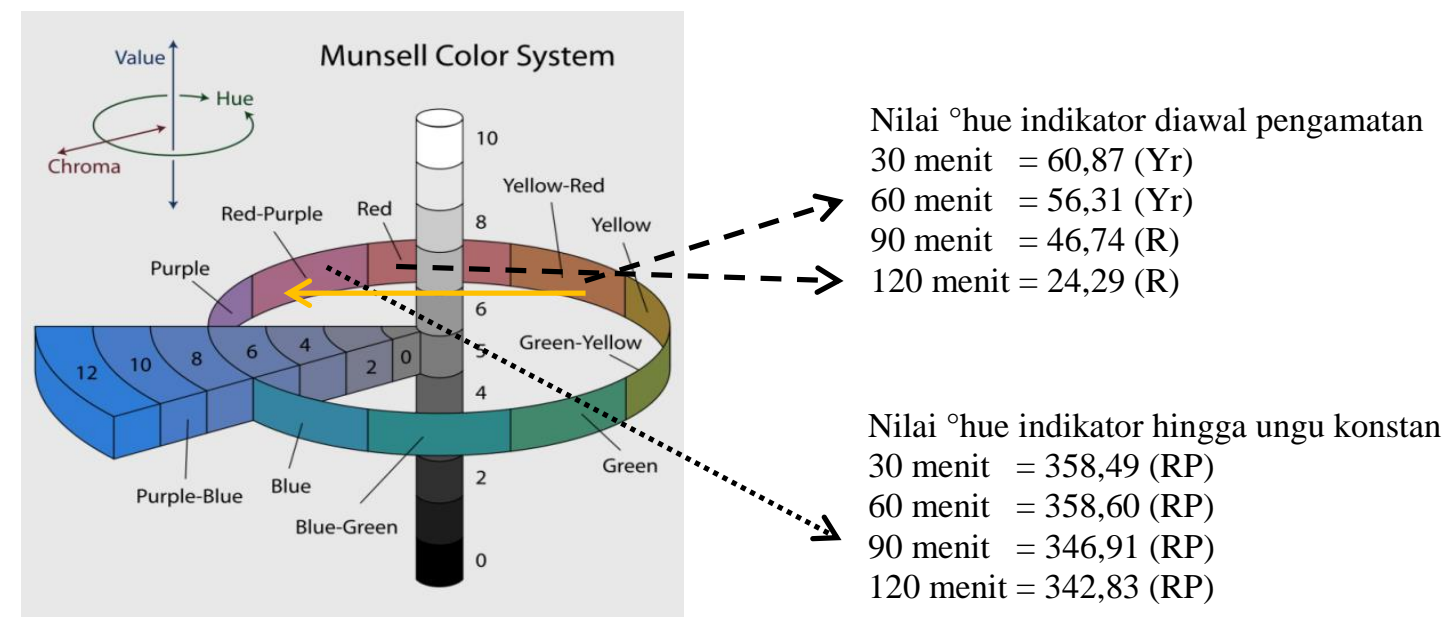

Gambar 8. Notasi warna Munsell color system (Mithare, 2015)

Gambar 8 menunjukkan notasi warna menurut Munsell. Menurut Andarwulan et al. (2011), keliling garis menyatakan warna kromatik pelangi. Warna kromatik dinyatakan dengan huruf dan angka. Secara umum warna indikator mengalami perubahan warna dari R dan Yr (red, yellow red) menjadi RP dan $\mathrm{P}$ (red purple, purple).

\section{KESIMPULAN DAN SARAN}

\section{Kesimpulan}

Jumlah $\mathrm{Ca}(\mathrm{OH})_{2}$ yang ditambahkan dan rasio mol glukosa terhadap metilen biru mempengaruhi waktu reduksi dan kadar air, sedangkan sensitivitas hanya dipengaruhi oleh rasio mol glukosa terhadap metilen biru.

Indikator kebocoran terbaik diperoleh dari perlakuan jumlah $\mathrm{Ca}(\mathrm{OH})_{2}$ yang ditambahkan sebesar $8 \mathrm{~g}$ dan rasio mol glukosa terhadap metilen biru 1,8:1.

Indikator kebocoran tersebut memiliki sifat irreversible dengan waktu reduksi 72 menit, waktu sensitivitas 31 detik dan kadar air sebesar 10,85\%.

Indikator kebocoran yang dikontakkan dengan oksigen laju alir $2 \mathrm{~L} /$ menit menunjukkan perubahan warna dari putih menjadi ungu dalam selang waktu 12 jam.

Uji kinerja tablet indikator secara visual memperlihatkan perubahan warna dari putih menjadi ungu ketika indikator kontak dengan oksigen dengan model kinetika perubahan indikator kebocoran mengikuti orde 0 dan orde 1 .

Notasi warna indikator menurut sistem Munsell mengalami perubahan warna dari $\mathrm{R}$ dan $\mathrm{Yr}$ (red,yellow red) menjadi RP dan $\mathrm{P}$ (red purple, purple).

\section{Saran}

Diperlukan penelitian lebih lanjut tentang aplikasi indikator kebocoran pada produk pangan sensitif oksigen agar dapat diketahuikorelasi perubahan warna indikator terhadap perubahan mutu produk.

\section{DAFTAR PUSTAKA}

[AOAC] Association of Official Analytical Chemist. 1995. Official Method of Analysis of Association of Official Analytical Chemist. $14^{\text {th }}$ Edition. Airlington (US): Association of Analytical Chemist.

Andarwulan N, Kusnandar F, dan Herawati D. 2011. Analisis Pangan. Edisi pertama. Jakarta : Dian Rakyat.

Dobrucka R. 2014. The use of oxygen indicatorselements of intelligent packaging for monitoring of food quality. Scientific Journal of Logistics. 10(2):183-190.

Fitria EA, Warsiki E, dan Yuliasih I. 2017. Model kinetika perubahan warna label indikator dari klorofil daun singkong (manihot esculenta Crantz). Jurnal Teknologi Industri Pertanian. 27(1): 17-23.

Kaas RL dan Darby D. 2010. An Oxygen Indicator for Assessment of Barrier Packaging. Clemson University: Kaas Consulting Group.

Matjik AA dan Sumertajaya M. 2000. Perancangan Percobaan dengan Aplikasi SAS dan Minitab. Bogor (ID): IPB Press.

Mills A. 2005. Oxygen indicators and intelligent inks for packaging food. Advance Article. 34:1003-1011,doi 10.1039/b503997p.

Masithoh RE, Rahardjo B, Sutiarso L, Harjoko A. 2013. Model kinetika perubahan kualitas tomat selama penyimpanan. Jurnal Teknologi Pertanian. 14(1): 21-28.

Mithare P. 2015. Munsell test [Internet]. [diakses 2018 April 29]. Tersedia pada : https://www.slideshare.net/prashantmithare/m unsell-test

Mohammadi A, Rafiee S, Emam ZD, Keyhani A. 2008. Kinetics models for colour changes in 
kiwifruits slices during hot air drying. World Journal of Agriculturan Sciences. 4(3): 376383.

Siquera JF dan Lopes HP. 1999. Mechanisms of antimicrobial activity of calcium Hydroxide: a critical review. International Endodontic Journal. 32: 361-369.

Smolander M, Hurne E, dan Ahvenainen R. 1997. Leak indicators for modified-atmosphere packages. Trends in Food Science \& Technology. 8: 101-106.

Sumitani M, Takagi S, Tanamura Y, Inoue H. 2004. Oxygen indicator composed of an organic/ inorganic hybrid compound of methylene blue, reductant, surfactant and saponite. Analytical Science. 20: 1153-1157.

Whistler RL dan Danie 1JR. 1985. Carbohydrates. Di dalam Fennema OR (ed.). Food Chemistry. New York and Basel: Marcel Dekker.

Winarno FG. 1997. Kimia Pangan dan Gizi. Jakarta (ID): Gramedia Pustaka.

Yam KT, Takhistov PT, dan Miltz J. 2005. Intelligent packaging: concepts and applications. Jounal Food Science. 70 (1): 1-10. 